\title{
Characterization of Sardinella fimbriata and Clarias gariepinus bones
}

\author{
WAN NOR ASIAH TUN MOHD ROSIDI, NURAINNI MOHD ARSHAD, NOR FAZLIYANA MOHTAR \\ Faculty of Fisheries and Food Science, Universiti Malaysia Terengganu. 21030 Kuala Nerus, Terengganu, Malaysia \\ Tel./fax.: +60-6684540/4949, `email: fazliyana@umt.edu.my
}

Manuscript received: 15 January 2020. Revision accepted: 2 February 2021.

\begin{abstract}
Rosidi WNATM, Arshad NM, Mohtar NF. 2021. Characterization of Sardinella fimbriata and Clarias gariepinus bones. Biodiversitas 22: 1621-1626. Calcium is one of the most important minerals required by the human body, which can be directly consumed from milk or any dietary supplement. This study was carried out to determine the calcium content in Fringescale sardinella (Sardinella fimbriata) and catfish (Clarias gariepinus) bones and compare their suitability for human consumption. Fish bones were cleaned, boiled, dried, and ground into powder. Bones from both species were white in color and odorless after drying. The protein content of S. fimbriata was measured to be $20.40 \pm 1.61 \%$, while for C. gariepinus it was $19.47 \pm 0.61 \%$. Ash content of S. fimbriata and $C$. gariepinus bones was $62.32 \pm 0.08 \%$ and $67.9 \pm 0.25 \%$, respectively. S. fimbriata bone exhibited $16.4 \pm 0.15 \%$ moisture, higher than C. gariepinus $(7.71 \pm 0.14 \%)$. The lipid content of $S$. fimbriata was $0.77 \pm 0.17 \%$ and for C. gariepinus it was $3.56 \pm 0.9 \%$. The solubility of $S$. fimbriata bone was $23.67 \pm 2.65 \%$, higher than that of in $C$. gariepinus bone $(9.02 \pm 2.19 \%)$. The calcium content found in S. fimbriata and C. gariepinus bones were $4.96 \pm 0.13 \mu \mathrm{g} / \mathrm{g}$ and $4.79 \pm 0.06 \mu \mathrm{g} / \mathrm{g}$, respectively. S. fimbriata bone exhibited higher solubility than that of $C$. gariepinus and was more suitable for human consumption. Overall findings have suggested the calcium from fish bones that may replace commercial calcium in the market, thus meeting the requirements of food safety standards.
\end{abstract}

Keywords: Calcium, composition, fishbone, characterization, proximate, solubility

\section{INTRODUCTION}

In Malaysia, especially in Terengganu, the production of keropok lekor is over 144 million tons annually. The production of keropok lekor involves processing the fish to obtain the muscle; the leftovers are usually discarded. Examples of fish by-products include the head, bones, skin, fins, and internal organs. Usually, people consume fish for protein and discard the bones. Fish bones are the main solid by-product that makes up 25 to $30 \%$ of fish weight (Tongchan et al. 2009; Terzioğlu et al. 2018). Fish bones contain valuable phosphorus and carbonates required by humans and their composition comprise about $2 \%$ of the whole fish (Malde et al. 2010). Most people consume milk and other dairy products for calcium, but some people may not be able to drink milk due to lactose indigestion and intolerance (Kim and Jung 2012). Based on previous studies, those who drink the most milk had more bone fractures and higher mortality than those who drank less (Michaëlsson et al. 2014). Therefore, fish bones are a better natural calcium source than milk. In addition, studies have also shown that the fish bones can be utilized in hydroxyapatite to reduce water pollution and as implant materials in bone replacements, heart valves, hip replacement, other implants in the human body, and many other applications (Aisyah et al. 2012; Shi et al. 2018; Sathiskumara et al. 2019; Ahuja et al. 2020; Hasan et al. 2021). This source of calcium can be effectively absorbed and has the potential to be an important dietary supplement, especially for those with low intakes of milk and dairy products.

Calcium is very important for building and maintaining strong bones. The heart, muscles, and nerves also need calcium to function properly, but excessive calcium intake can have side effects like heart attack. Most people consume milk or dairy products for calcium sources in their body (Anderson and Garner, 1996). Previous studies determined that the calcium content of fish bones is high. However, such findings were very limited and focused mainly on extraction. To the best of our knowledge, there were limited findings in the literature on the extraction of calcium from sardinella (Logesh et al. 2012; Hamada et al. 1995) and catfish (Luu and Nguyen 2009) species. Therefore, this study was carried out to determine the proximate and physical properties of both Fringescale sardinella (Sardinella fimbriata) and catfish (Clarias gariepinus) bones. The proximate and physical properties of calcium extracted from these two species could also be used as an alternative in calcium sources. Findings from this study may contribute to better management of fisheries by-products by utilizing fish resources at a maximum level. In addition, they can be used to produce calcium supplements based on the fish by-products that can be found easily in Malaysia.

\section{MATERIALS AND METHODS}

\section{Fish samples}

Fish bones were collected from the local fish processing industry in Kuala Nerus, Terengganu, Malaysia, and were brought to the hatchery at Universiti Malaysia Terengganu (UMT). Fringescale sardinella (Sardinella fimbriata) and catfish (Clarias gariepinus) bones were transferred to the laboratory at UMT. All bones were boiled, dried, cleaned, and stored at $-20^{\circ} \mathrm{C}$ until used. 


\section{Fish bone preparation}

Fish bones were cleaned of any flesh and blood. They were boiled until they became white and no excess flesh remained attached to the bones. The water was changed every hour, and the bones were rinsed several times. These steps were repeated until the bones were cleaned of any flesh attached to the bones. The bones were dried in an oven until no water remained at the surface before being ground into powder. The powders made from the bones of the two species were stored in a dry place until use.

\section{Fish bone characterization}

Physical appearance

The physical characteristics of the fish bone powders were assessed according to the criteria described by Phiraphinyo et al. (2006). The physical characteristics of $S$. fimbriata and C. gariepinus bones were observed for odor and color before and after drying in an oven.

\section{Proximate analysis}

The proximate analysis in terms of protein, ash, moisture, and lipids content was conducted according to the method of AOAC (2000).

\section{Protein}

Fish bone powder was placed in digestion flask and 5 $\mathrm{mL}$ sulphuric acid $\left(\mathrm{H}_{2} \mathrm{SO}_{4}\right)$ was added. The flask was shaken well and was placed on a rack for heating. The digestion process was conducted for 40 minutes until a clear blue-green solution formed. The flask was cooled down for 15 mins and transferred to distillation unit. A $32 \%$ sodium hydroxide $(\mathrm{NaOH})$ was slowly added until the color changed to blue. The resulting solution was steam distilled for 4 minutes into $60 \mathrm{~mL}$ of $2 \%$ boric acid $\left(\mathrm{H}_{3} \mathrm{BO}_{3}\right)$ containing 10 drops of indicator solution. The alkaline ammonium borate formed was titrated with standard hydrochloric acid $(\mathrm{HCl})(0.1 \mathrm{M})$.

The protein content of S. fimbriata and C. gariepinus bones was calculated based on the following formulas:

$$
\begin{aligned}
& \mathrm{N}(\%)=\mathrm{F} \times 14 \times(\text { volume of } \mathrm{HCl}) \times(\text { Normality } \mathrm{HCl}) / \\
& (\text { Weight of gelatine }(\mathrm{g}) \times 1000 \mathrm{~mL}) \times 100
\end{aligned}
$$

Where: $\mathrm{F}=$ Conversion factor $(6.25)$

\section{Ash}

Crucibles that contained fish bone powder were placed on a hot plate and $0.5 \mathrm{~mL}$ of nitric acid $\left(\mathrm{HNO}_{3}\right)$ was added. The temperature was increased and the fish bone powder was left to become wet ash for 45 minutes until white smoke was no longer produced. This process was conducted in a fume chamber. The crucibles were then placed into a muffle furnace, and the fish bone powder was heated for 3 hours at $600^{\circ} \mathrm{C}$. The lid was placed on top of the crucible during heating process to prevent ash loss. The sample was then cooled in desiccator.

The percentage of ash was calculated by the following formula:

Ash $(\%)=($ Weight of ash $(\mathrm{g})) /($ Weight of fish bone powder $(\mathrm{g})) \times 100$

\section{Moisture}

Fish bone powder was placed in a crucible and dried in an oven at $100^{\circ} \mathrm{C}$ for 24 hours until its weight became constant. The crucible was transferred into desiccator for cooling with partially covered lid. Moisture content was calculated as a percentage of weight loss of the sample after the drying process.

The moisture content of S. fimbriata and C. gariepinus was calculated with the following formula:

Moisture $(\%)=($ Fish bone powder $(\mathrm{g})$-Dried fish bone powder $(\mathrm{g})) /($ Fish bone powder $(\mathrm{g})) \times 100$

\section{Lipids}

Empty thimble and fish bone powder were weighed. The fish bone powder was placed in a Soxhlet extractor. Lipid content was extracted with $50 \mathrm{~mL}$ petroleum ether and evaporated. Time was set for 1 hour where 15 mins for boiling, 30 mins for rinsing, 10 mins for steam and 5 mins for drying at a $900^{\circ} \mathrm{C}$ for petroleum ether to get solvent reflux stage until it gets 3 to 5 drops per second. The temperature was then decreased to $90^{\circ} \mathrm{C}$ and the thimble was alighted until boiling. After 15 mins, the thimble was removed at the rinsing positions. The samples were placed in an oven for 2 hours at $100^{\circ} \mathrm{C}$ for the drying process.

The following calculation was used to determine the amount of lipid content in the fishbone powder:

Lipid $(\%)=($ Weight of the extracted lipid content $(\mathrm{g})) /$ (Weight of fish bone powder $(\mathrm{g})) \times 100$

\section{Solubility}

The solubility of the fish bone powder was determined by following the method of Hemung (2013). Fish bone powder $\left(\mathrm{W}_{1}\right)$ was mixed with distilled water at a ratio of 1:4 (fish bone powder: water) and stirred at $25^{\circ} \mathrm{C}$ for 12 hours. The mixture was filtered through filter paper (No. 1, Whatman), and the filtered solid $\left(\mathrm{W}_{2}\right)$ was dried to obtain the insoluble particles.

The solubility of the fish bone powder was calculated with the following formula:

$$
\text { Solubility }(\%)=\left(\mathrm{W}_{1}-\mathrm{W}_{2}\right) / \mathrm{W}_{1} \times 100
$$

\section{Calcium $\left(\mathrm{Ca}^{2+}\right)$ content}

The calcium $\left(\mathrm{Ca}^{2+}\right)$ content of fish bone powder was determined using the wet ashing method described by Sembok (2013). A crucible containing $1 \mathrm{~g}$ of fish bone powder was placed in a muffle furnace and dried at $500^{\circ} \mathrm{C}$ for 12 hours. It was left to cool to $25^{\circ} \mathrm{C}$, and $2 \mathrm{~mL}$ of concentrated $\mathrm{HCl}$ were added to the crucible and evaporated to dryness on a hot plate. Approximately $10 \mathrm{~mL}$ $\mathrm{HNO}_{3}(4.8 \mathrm{M})$ was added to the crucible before it was placed in a water bath for 1 hour. The mixture was transferred into a $100 \mathrm{~mL}$ volumetric flask and distilled water was added until a total volume of $100 \mathrm{~mL}$ was reached. It was then filtered through filter paper (No. 2, Whatman). 


\section{Data analysis}

The data were analyzed with the independent samples T-test. Levene's test was performed for equality of variances, followed by a T-test to compare the mean between samples in SPSS (version 22) at $p<0.05$ levels, which were considered significant.

\section{RESULTS AND DISCUSSION}

\section{Physical appearance}

In this experiment, the bones of $S$. fimbriata and $C$. gariepinus remain white before and after drying in an oven. Oven drying also causes the smell of the fish bones to disappear (Table 1). According to research, fish bone powders generally appear as fine white particles and have no fishy odor. These fish bone powders may be suitable for incorporating into diverse products (Luu and Nguyen 2009). Photographs of the physical appearance of the $S$. fimbriata and $C$. gariepinus bone powders before and after drying are shown in Figure 1.

\section{Proximate analysis}

Protein

Sardinella fimbriata and C. gariepinus bones were analyzed and the results are shown in Table 2 . The protein contents of $S$. fimbriata and $C$. gariepinus bones were $20.40 \pm 1.61 \%$ and $19.47 \pm 0.61 \%$, respectively. There were no significant differences between them at $p<0.05$. The protein content of tilapia bone was found to be $14.81 \%$ (Hemung 2013), and for blue whiting, salmon, trout, herring, and mackerel, bone protein contents were in the range of $26-41 \%$ (Toppe et al. 2007). Therefore, the bone protein content of $C$. gariepinus was higher than that of tilapia. Both $C$. gariepinus and tilapia are local fish, whereas blue whiting, salmon, trout, herring, and mackerel are cold seawater fish. In previous studies, most of the fish meat was removed from the bones with a hot alkaline solution, while in this study it was done by boiling the bones in hot water. Alkaline solution would be more effective in removing muscle tissues, but not effective enough to get rid of the protein.

\section{Ash}

Ash is a major component of fish bones that acts as a mineral content indicator. The ash content of S. fimbriata bone $(62.32 \pm 0.08 \%)$ was significantly lower than that of C. gariepinus bone $(67.90 \pm 0.25 \%)$ at $p<0.05$. Tilapia bone was found to have $75 \%$ ash content (Hemung 2013). The ash in tilapia bone was higher than that of $S$. fimbriata and $C$. gariepinus bones, but there was not much difference between them. The ratio of ash to protein is an important criterion to indicate the bone mineralization associated with the hardness of the bone. The ratio of ash to protein for $S$. fimbriata bone was 3.05 and for $C$. gariepinus bone it was 3.49 , both lower than tilapia bone, which was 5.35. The preparation method may also affect the value, and it can be used to estimate the purity of the bone (Hemung 2013).

\section{Moisture}

The moisture content of $S$. fimbriata bone was twice that of $C$. gariepinus. The two species were significantly different in terms of their moisture content, which was $16.40 \pm 0.15 \%$ for $S$. fimbriata and $7.71 \pm 0.14 \%$ for $C$. gariepinus $(p<0.05)$. In previous studies, it was shown that water molecules did not penetrate into the bone tissue, but instead were bound weakly to the surface (Tont et al. 1977). The moisture content of tilapia was $2.46 \%$ lower than that of S. fimbriata and C. gariepinus (Hemung 2013). This may be due to incomplete drying during fish bone preparation, but that value is small enough to avoid microbial growth. Low moisture content would also make the powders stable even at room temperature, allowing them to be safely used as an ingredient in many applications.

Table 1. Physical appearance of Sardinella fimbriata and Clarias gariepinus bones before and after drying

\begin{tabular}{lll}
\hline \multicolumn{1}{c}{ Bone powder } & \multicolumn{1}{c}{ Pefore drying } & \multicolumn{1}{c}{ After drying } \\
\cline { 2 - 3 } & \multicolumn{1}{c}{ Phsical appearance } \\
\hline Standard $\mathrm{CaCO}_{3}$ & White odorless powder & Yellowish odorless powder \\
Sardinella fimbriata & White odorous powder & White odorless powder \\
Clarias gariepinus & White odorous powder & White odorless powder \\
\hline
\end{tabular}

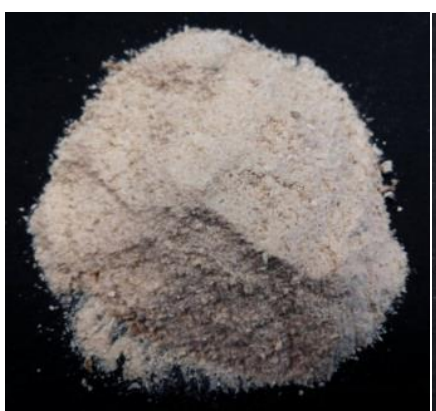

A
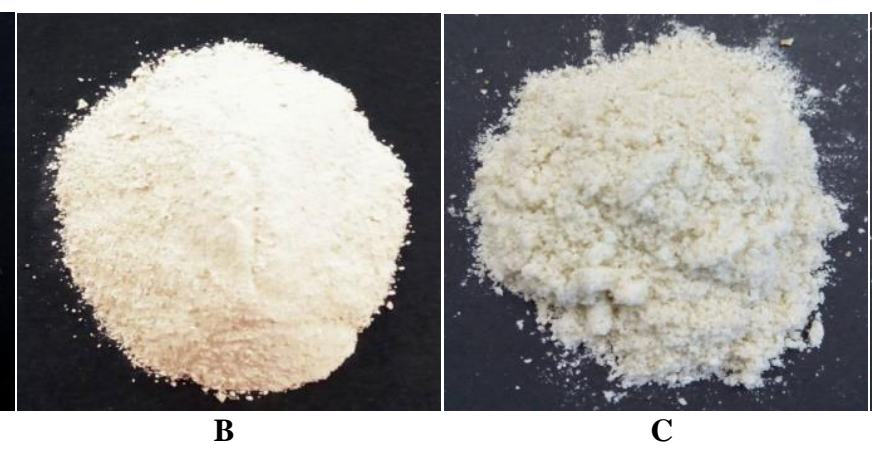

C

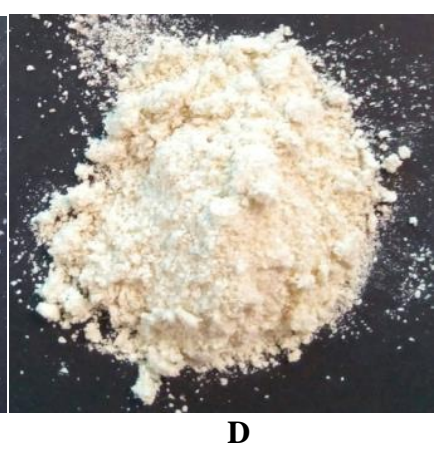

Figure 1. A. Sardinella fimbriata fish bone powder before drying in the oven; B. S. fimbriata fish bone powder after drying in the oven; C. Clarias gariepinus bone powder before drying in the oven; D. C. gariepinus bone powder after drying in the oven 
Table 2. Proximate composition of Sardinella fimbriata and Clarias gariepinus bones

\begin{tabular}{lcc}
\hline \multirow{2}{*}{ Proximate composition } & \multicolumn{2}{c}{ Content $(\%)$} \\
\cline { 2 - 3 } & \multicolumn{1}{c}{ S. fimbriata } & \multicolumn{1}{c}{ C. gariepinus } \\
\hline Protein & $20.40 \pm 1.61^{\mathrm{a}}$ & $19.47 \pm 0.61^{\mathrm{a}}$ \\
Ash & $62.32 \pm 0.08^{\mathrm{b}}$ & $67.90 \pm 0.25^{\mathrm{a}}$ \\
Moisture & $16.40 \pm 0.15^{\mathrm{a}}$ & $7.71 \pm 0.14^{\mathrm{b}}$ \\
Lipid & $0.77 \pm 0.17^{\mathrm{b}}$ & $3.56 \pm 0.90^{\mathrm{a}}$ \\
\hline
\end{tabular}

Note: Values are the mean \pm standard deviation of triplicate samples. ${ }^{a-b}$ Means with the same superscripts within a row are not significantly different $(p<0.05)$.

Table 3. Solubility of fish bones and calcium $\left(\mathrm{Ca}^{2+}\right)$ content in Sardinella fimbriata and Clarias gariepinus bones

\begin{tabular}{lcc}
\hline Quality attributes & S. fimbriata & C. gariepinus \\
\hline Solubility $(\%)$ & $23.67 \pm 2.65^{\mathrm{a}}$ & $9.02 \pm 2.19^{\mathrm{b}}$ \\
Calcium content $(\mu \mathrm{g} / \mathrm{g})$ & $4.96 \pm 0.10^{\mathrm{a}}$ & $4.79 \pm 0.06^{\mathrm{a}}$ \\
\hline Note: Values are the mean \pm standard deviation of triplicate \\
samples. a-b Different lowercase superscripts & within a row are \\
significantly different $(p<0.05)$
\end{tabular}

\section{Lipids}

Clarias gariepinus is a fatty fish while $S$. fimbriata is lean, and the lipid content of bone is correlated with body fat. Hence, the lipid content of $C$. gariepinus bone was 3.56 $\pm 0.90 \%$, which was significantly higher than that of $S$. fimbriata, which was only $0.77 \pm 0.17 \%$ at $p<0.05$. Lipid could infiltrate the bone, which contains a junction of many pieces of bone, especially in the main bone of the fish frame (Phleger, 1975). In a study of the nutritional values of boiled and smoked C. gariepinus, the bones of boiled fish were found to contain $2.11 \%$ lipids versus $1.95 \%$ for smoked fish (Adeniji et al. 2015). This result was very close to the current study. S. fimbriata is considered a lowfat fish species because it contains low fat even in the adult stage. Therefore, S. fimbriata and C. gariepinus bones should have less risk of autoxidation since they contain little fat content.

\section{Solubility of fish bone and calcium $\left(\mathrm{Ca}^{2+}\right)$ content}

The fish bone powder was not solubilized completely (Table 3). However, S. fimbriata bone demonstrated solubility of $23.67 \pm 2.65 \%$, which was significantly higher than that of $C$. gariepinus $(9.02 \pm 2.19 \%)$ at $p<0.05$. This suggested that not all mineral components could be absorbed. C. gariepinus bone powder is almost completely mineralized because the bone is hard. Hemung (2013) stated that the bones of old fish are hard and will mineralize completely. There are a few factors affecting the solubility of minerals in fish bones, including species and age. The solubility of fish bone is related to the absorption of minerals in the body. Calcium $\left(\mathrm{Ca}^{2+}\right)$ in fish bones is soluble and absorbed readily into the human body (Larsen et al. 2000). Based on this study, S. fimbriata bone demonstrated higher solubility compared to the $C$. gariepinus bone. Therefore, calcium in $S$. fimbriata bone can be absorbed more readily by the human body than calcium from C. gariepinus bone.

There was no significant difference in $\mathrm{Ca}^{2+}$ content between $S$. fimbriata and $C$. gariepinus bones at $p<0.05$. The value of $\mathrm{Ca}^{2+}$ in S. fimbriata was $4.96 \pm 0.13 \mu \mathrm{g} / \mathrm{g}$ while for C. gariepinus it was $4.79 \pm 0.06 \mu \mathrm{g} / \mathrm{g}$. The $\mathrm{Ca}^{2+}$ contents were obtained by analyzing the solutions made from the bone powders of each species. The stock solutions were diluted to obtain samples that contained 2, 4, 6, 8, and $10 \mathrm{mg} / \mathrm{L}$ of fish bone powder. Hence, the actual value of $\mathrm{Ca}^{2+}$ in S. fimbriata was $2480.7 \mu \mathrm{g} / \mathrm{g}$ while in C. gariepinus is $2392.85 \mu \mathrm{g} / \mathrm{g}$. The variability of $\mathrm{Ca}^{2+}$ content in bone might depend on fish species, the amount of marrow in the bone, cartilage, whether the fish is lean or fatty, and tendons on the surface of the bone (Luu and Nguyen 2009). In a previous study, the calcium content in tilapia bone was reported to be $2376.00 \mu \mathrm{g} / \mathrm{g}$ (Hemung and Sriuttha 2014). The cellular bone from fish in the Salmonidae family is less strained than acellular bone because of the lower surfaceto-volume ratio in cellular bone (Hemung 2013). S. fimbriata and $C$. gariepinus bones were classified as acellular. Hemung (2013) demonstrated that $\mathrm{Ca}^{2+}$ could be more available from acellular bone, and tilapia bone is acellular.

$\mathrm{Ca}^{2+}$ contents obtained from Atlantic salmon and Baltic cod backbones were $24.92 \%$ and $27.79 \%$, respectively (Bubel et al. 2015). The result was similar for ribbon fish (Trichiurus savala), which contained $27.81 \% \mathrm{Ca}^{2+}$. While for oil sardines (Sardinella longiceps), the $\mathrm{Ca}^{2+}$ content was $32.73 \%$ (Logesh et al. 2012). Xavier et al. (2014) investigated the $\mathrm{Ca}^{2+}$ content in Sardinella fimbriata (31.98\%), Sardinella gibbosa (28.34\%), and Sardinella albella (26.02\%). The values of $\mathrm{Ca}^{2+}$ might differ among these species because of the different bone preparation processes. Based on all the research, it is quite evident that the bones from low-value fish like Sardinella spp. are rich in calcium.

\section{Relation of calcium $\left(\mathrm{Ca}^{2+}\right)$, solubility and absorbability}

Ash is considered an indicator of mineral content in a sample. Mineral uptake by the human body also depends on the solubility and availability of the mineral to be absorbed. In addition, the solubility of minerals influences the quality of ash (Hemung 2013). High solubility may lead to high absorption of calcium $\left(\mathrm{Ca}^{2+}\right)$ in bone but low solubility does not necessarily mean low bioavailability (Heaney et al. 1989; Heaney et al. 1990; Koo et al. 1993). Low $\mathrm{pH}$ in the stomach causes all $\mathrm{Ca}^{2+}$ to change into a different ionic form and precipitate as insoluble calcium phosphate (Jung et al. 2008). However, absorption of calcium takes place in the small intestine where the $\mathrm{pH}$ is commonly 6.5 , but the human body cannot absorb the calcium present in precipitated calcium phosphate (Heaney et al. 1990; Jung et al. 2008). 


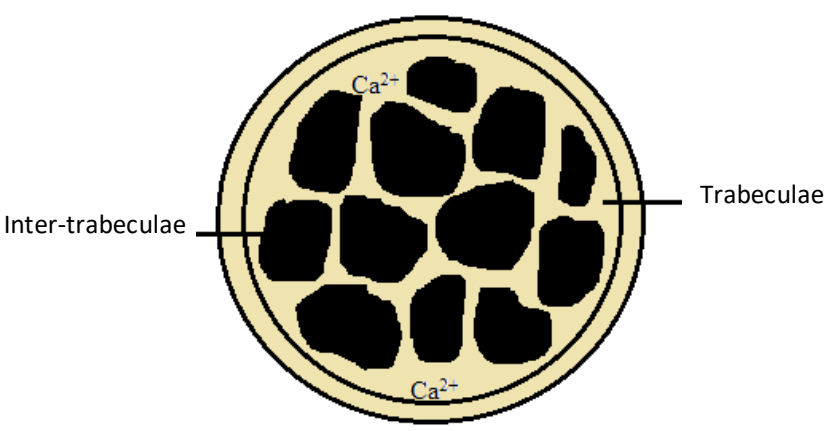

Figure 2. Illustration of bone structure with low calcium content. Inter-trabeculae increase in size and trabeculae become thinner and more weakly connected

Hence, soluble calcium is still important, although the relationship between solubility and absorbability is weak. High absorption can occur due to high $\mathrm{Ca}^{2+}$ content. Research by Tongchan et al. (2009) tested different quantities of $\mathrm{Ca}^{2+}$ content on Wistar rats to determine the effect and absorption of $\mathrm{Ca}^{2+}$ in urine, feces and bone. The treatments were $0,11,22$ and $44 \mathrm{mg} \mathrm{Ca} / \mathrm{d}$. In bone histology, the thickest trabeculae and narrowed intertrabeculae were present in rats receiving the highest treatment. The absorption of $\mathrm{Ca}^{2+}$ in bones will also cause bone mass to increase. The bone masses of the rats were compared between those with standard and low $\mathrm{Ca}^{2+}$ intake. Rats with standard $\mathrm{Ca}^{2+}$ intake showed higher bone mass than low $\mathrm{Ca}^{2+}$ intake (Kim and Park 2013).

It has been hypothesized that $\mathrm{Ca}^{2+}$ is very important because it supports bone growth and development. It is absorbed into the trabeculae of bone during the calcium homeostasis process. Trabeculae are structures that support spongy bone tissue. They connect to each other with thin rods and plates of bone tissue. Inter-trabeculae is the spaces between trabeculae. Calcium homeostasis is the process by which $\mathrm{Ca}^{2+}$ moves into the bone as osteoblasts build new bone and out of bone as osteoclasts break it down. If there is less $\mathrm{Ca}^{2+}$ available, $\mathrm{Ca}^{2+}$ from bone will be released into the bloodstream to increase the blood calcium level; bone that lacks $\mathrm{Ca}^{2+}$ will fracture more easily. Tongchan et al. (2009) found that the size of trabeculae was greater with increased $\mathrm{Ca}^{2+}$ intake and trabeculae became thinner when $\mathrm{Ca}^{2+}$ intake was reduced. Figure 2 shows an illustration of bone structure when $\mathrm{Ca}^{2+}$ intake is low. The intertrabeculae spacing is greater, and trabeculae are thinner. This makes the bone easier to fracture. Figure 3 is an illustration of bone structure with high $\mathrm{Ca}^{2+}$ intake. Trabeculae are thicker, with high connectivity and narrow inter-trabeculae.

In conclusion, Fringescale sardinella (Sardinella fimbriata) showed a higher calcium content than catfish (Clarias gariepinus). The solubility of S. fimbriata bone was also higher than that of $C$. gariepinus bone. Therefore, more minerals can be absorbed into the human body from $S$. fimbriata due to its high solubility. Hence, S. fimbriata bone is the best fish bone for human consumption. Previous studies have confirmed that bones from low-value species

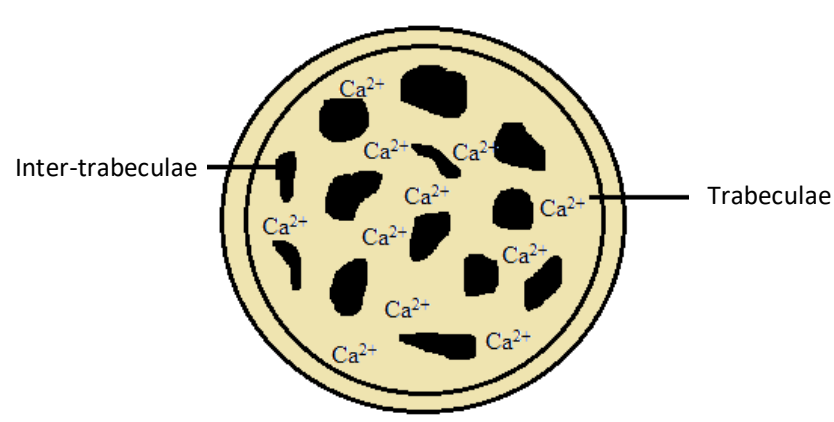

Figure 3. Illustration of bone structure with high calcium content. Trabeculae increase in size and become more strongly connected while inter-trabeculae become narrower

like Sardinella spp. are rich in calcium content; therefore, it should be recommended for human consumption either directly or indirectly through the production of calciumenriched nutraceuticals. The phosphorus content of fish bones could also be analyzed in future studies as it is required for calcium transportation. In addition, cytotoxicity testing could be carried out to determine the effect of calcium absorption from the bones of different fish species.

\section{ACKNOWLEDGEMENTS}

The authors would like to acknowledge the Faculty of Fisheries and Food Science and the Central Lab at Universiti Malaysia Terengganu (UMT) for providing access to facilities and materials for completion of the experiments. This research did not receive any specific grants from funding agencies in the public, commercial, or not-for-profit sectors.

\section{REFERENCES}

Adeniji AR, Ayoade O, Akinwande BO, Oludare O. 2015. Nutrition evaluation of boiled and smoked catfish (Clarias gariepinus) using different parts (bone, skin and flesh). Intl J Innov Res Sci Eng Technol 4(10): 10465-10469.

Ahuja I, Dauksas E, Remme JF, Richardsen R, Løes A-K. 2020. Fish and fish waste-based fertilizers in organic farming-With status in Norway: A review. Waste Manag 115: 95-112.

Aisyah D, Mamat I, Sontang M, Rosufila Z, Ahmad NM. 2012. Program pemanfaatan sisa tulang ikan untuk produk hidroksiapatit: Kajian di pabrik pengolahan kerupuk lekor Kuala Terengganu-Malaysia. Jurnal Sosioteknologi 26: 129-141. [Malaysian]

Anderson JJB, Garner SC. 1996. Calcium and phosphorous nutrition in health and disease. In Calcium and Phosphorous in Health and Disease. (JJB Anderson and SC Garner, Eds). CRC Press, New York.

AOAC. 2000. Official Methods of Analysis (17 th $\mathrm{ed)}$. Association of Official Analytical Chemist, Washington. D.C.

Bubel F, Dobrzański Z, Bykowski PJ, Chojnacka K, Opaliński S, Trziszka T. 2015. Production of calcium preparations by technology of saltwater fish by product processing. Open Chem 13: 1333-1340.

Calvo MS. 1993. Dietary phosphorus, calcium metabolism and bone. J Nutr 123 (9): 1627-1633.

Changhu X, Zhaojie L, Cheng S, Zhongliang W. (1995). Studies on the preparation of active calcium from Pollack frame. J Qingdao Ocean Univ 25 (2): 173-178. 
Hamada M, Nagai T, Kai N, Tanoue Y, Mae H, Hashimoto M, Miyosh K, Kumagai H, Saeki K. 1995. Inorganic constituents of bone of fish. Fish Sci 63: 517-520.

Hasan MR, Mohd Yasin NS, Mohd Ghazali MS, Mohtar NF. 2020. Proximate and morphological characteristics of nano hydroxyapatite (Nano HAp) extracted from fishbone. J Sustain Sci Manag 15 (8): 921.

Heaney RP, Recker RR, Weaver, M. 1990. Absorbability of calcium sources: The limited role of solubility. Calcif Tiss Intl 46: 300-304.

Heaney RP, Smith KT, Recker RR, Hinders SM. 1989. Meal effects on calcium absorption. Am J Clin Nutr 49: 372-376.

Hemung BO. 2013. Properties of tilapia bone powder and its calcium bioavailability based on transglutaminase assay. Intl $\mathrm{J}$ Biosci Biochem Bioinform 3 (4): 306-309.

Hemung BO, Sriuttha M. 2014. Effects of tilapia bone calcium on qualities of tilapia sausage. Kasetsart J Nat Sci 48 (5): 790-798.

Jung WK, Shahidi F, Kim SK. 2008. Calcium from fishbone and other marine resources. Marine Nutraceut Funct Foods 17: 419-426.

Kim C, Park D. 2013. The effect of restriction of dietary calcium on trabecular and cortical bone mineral density in the rats. J Exercise Nutr Biochem 17 (4): 123-131.

Kim SK, Jung WK. 2012. Beneficial effect of teleost fish bone peptide as mineralization. Adv Food Nutr Res 65: 287-95.

Koo J, Weaver CM, Neylan MJ. 1993. Solubility of calcium salts and carrageenan used in infant formulas did not influence calcium absorption in rats. J Pediatric Gastroenterol Nutr 17: 298-302.

Larsen T, Thilsted S.H, Kongsbak K, Hansen M. 2000. Whole small fish as a rich calcium source. Br J Nutr 83: 191-196.

Logesh AR, Pravinkumar M, Raffi S.M, Kalaiselvam M. 2012. Calcium and phosphorus determination in bones of low-value fishes, Sardinella longiceps (Valenciennes) and Trichiurus savala (Cuvier), from Parangipettai, southeast coast of India. Asian Pac J Trop Dis 2012: S254-S256.

Luu PH, Nguyen MH. 2009. Recovery and utilization of calcium from fish bones by-products as a rich calcium source. J Sci Technol 47 (6) 91-103.

Malde MK, Bügel S, Kristensen M, Malde K, Graff IE, Pedersen JI. 2010 Calcium from salmon and cod bone is well absorbed in young healthy men: A double-blinded randomised crossover design. Nutr Metabolism 7: 61. DOI: 10.1186/1743-7075-7-61.
Michaëlsson K, Wolk A, Langenskiöld S, Basu S, Lemming E.W, Melhus H, Byberg, L. 2014. Milk intake and risk of mortality and fractures in women and men: cohort studies. $\mathrm{Br}$ Med J 2014; 349. DOI: 10.1136/bmj.g6015.

Phiraphinyo P, Taepakpurenat S, Lakkanatinaporn P, Suntornsuk W, Suntornsuk L. 2006. Physical and chemical properties of fish and chicken bones as calcium source for mineral supplements. Songklanakarin J Sci Technol 28 (2): 327-335.

Phleger CF. 1975. Bone lipids of Kona coast reef fish: Skull buoyancy in the hawkfish, Cirrhites pinnulatus. Comp Biochem Physiol 52B: 101-104.

Sathiskumara S, Vanaraj S, Sabarinathan D, Bharath S, Sivarasan G, Arulmani S, Preethi K, Ponnusamy VK. 2019. Green synthesis of biocompatible nanostructured hydroxyapatite from Cirrhinus mrigala fish scale-A biowaste to biomaterial. Ceramics Intl. 45: 7804-7810.

Sembok W.Z.W. 2013. Botany and Plant Physiology (GTN3300). Universiti Malaysia Terengganu, Malaysia.

Shi P, Liu M, Fan F, Yu C, Lu W, Du M. 2018. Characterization of natural hydroxyapatite originated from fishbone and its biocompatibility with osteoblasts. Mat Sci Eng C-Mater Biol Appl 90: 706-712.

Terzioğlua P, Öğütc H, Kalemtaş A. 2018. Natural calcium phosphates from fish bones and their potential biomedical applications. Mater Sci Eng C 91: 899-911.

Tongchan P, Prutipanlai S, Niyomwas S, Thongraung C. 2009. Effect of calcium compound obtained from fish by-product on calcium metabolism in rats. Asian J Food Agro-Industry 2 (4): 669-676.

Tont SA, Pearcy WG, Arnold JS. 1977. Bone structure of some marine vertebrates. Mar Biol 39: 191-196.

Toppe J, Albrektsen S, Hope B, Aksnes A. 2007. Chemical composition, mineral content and amino acid and lipid profiles in bones from various fish species. Compar Biochem Physiol B Biochem Mol Biol 146 (3): 395-401.

Xavier EL, Pravinkumar M, Logesh AR, Viswanathan C, Raffi SM. 2014. Estimation of calcium and phosphorus in bones of three low-value fishes Sardinella fimbriata, Sardinella albella and Sardinella gibbosa from Muttom, southeast coast of India. Intl J Curr Trends Res 3 (2): 43-46. 